\title{
Odstranění řeholních sester z jihočeských nemocnic komunistickým režimem a jeho dopad na pastoraci nemocných
}

\author{
Martin Weis
}

\section{Úvodem}

Po únoru 1948 nastalo postupné omezování náboženského života ve státě. Komunistický režim se v Československu snažil ovládnout křestanské církve. Činil tak v prvé řadě pomocí mocenských prostř̌edků - šlo o znemožnění adekvátní reakce církví na společenské změny v Československu, o zabavení hospodářské základny církví, ale také o postupné odstranění mnohých představitelů církví a jejich internování či uvěznění v důsledku zinscenovaných politických procesů. ${ }^{1}$

Dalším cílem komunistické moci bylo nejdřive vytlačit vněšš́ projevy náboženského života obyvatel Československa $z$ veřejného života a veřejných prostor do uzavřených prostor bohoslužebných, které měly být dále postupně co do počtu omezovány tak, jak měl podle představ vládnoucí moci klesat počet těch, pro které bylo zapotřebí zajistit tzv. „náboženské vyžiti“. To s sebou neslo i omezování možností pastorace nemocných ve veřejných nemocnicích. Bylo postupováno od odstranění kř́ǐž $z$ veřejných prostor nemocnic přes rušení nemocničních kaplí až $\mathrm{k}$ vypuzení řeholních sester $\mathrm{z}$ nemocnic, aby nemohly „negativně světonázorově působit“ na pacienty i personál nemocnic. Nakonec pro pastoraci nemocných zůstal duchovním pouze krátký vymezený prostor tichého rozhovoru $s$ nemocným $v$ rámci tzv. návštěvních hodin nemocných př́buznými a přáteli.

Tato studie si klade za cíl přiblížit odstranění řeholních sester $\mathrm{z}$ nemocnic $\mathrm{v}$ jihočeském regionu a následný negativní dopad na pastoraci nemocných, zejména na základě archivních materiálů i odborné literatury. Pro rozsáhlost tématu byly v této studii vybrány pouze větší nemocnice, ve kterých působila kongregace Milosrdných sester sv. Karla Boromejského, a to v Českých Budějovicích, Jindřichově Hradci, Písku, Pelhřimově, Strakonicích a Táboře.

\footnotetext{
1 Srov. Václav VAŠKO, Neumlčená: Kronika katolické církve v Československu po drubé světové válce I, Praha: Zvon, 1990 , s. 243-245. Dále srov. Václav VAŠKO, Dỉm na skále 1, Církev žoušená: 1945 - začátek 1950, Kostelní Vydř́i: Karmelitánské nakladatelství, 2004. K problematice politického katolicismu je možné směle doporučit velmi zasvěcenou monografii Petr FIALA, Český politický katolicismus 1848-2005, Brno: Centrum pro studium demokracie a kultury, 2008.
} 


\section{K problematice literatury a pramenů}

K problematice perzekuce řeholníků a řeholnic komunistickým režimem bylo publikováno již několik monografií, studií a kvalifikačních prací. Dlužno konstatovat, že našeho tématu se však dotýkají pouze okrajově či dílčím způsobem. ${ }^{2}$

Nejcennější zdroj informací k námi zkoumané problematice přináší státní archivy, ve kterých jsou uloženy materiály státních úředníků z jihočeského regionu, kteří měli v kompetenci takzvaný dohled státu nad církvemi. Materiály z jejich činnosti jsou soustředěny ve Státním oblastním archivu v Třeboni a též částečně v okresních archivech, a to jako součásti archivních fondů KNV a ONV - církevních referátů, oddělení či odborů. Dále byly v této studii použity archivní materiály z majetku autora, které získal při sběru dokumentů týkajících se postavy českobudějovického biskupa Josefa Hloucha, nebot' ony přibližují reakci biskupa na likvidaci řeholního života na území jeho diecéze. Nebyly opomenuty ani tištěné archivní materiály jako diecézní katalog či úřední věstníky a oběžníky státní správy. Tam, kde to bylo nezbytně nutné pro zasazení tématu do širších souvislostí, jsou citovány i materiály $\mathrm{z}$ ústř̌edních archivů - kuprríkladu materiály Státního úřadu pro věci církevní v Praze.

\section{Situace řeholnic a pastorační péče o nemocné po roce 1948}

Pokud pohlédneme do precizně vypracovaného českobudějovického diecézního katalogu, zjistíme, že na území českobudějovické diecéze působilo k 1. lednu 1948 celkem 612 řeholních sester, $\mathrm{z}$ toho bylo celkem 163 sester boromejek. Ty pracovaly zejména v okresních a městských nemocnicích. Katalog uvádí, že v okresní nemocnici České Budějovice to byl kolektiv 42 sester, vokresní nemocnici Jindřichův Hradec to bylo 8 sester, v městské nemocnici Pelhřimov byl kolektiv 18 sester, komunita 14 sester pracovala v okresní nemocnici v Písku a 8 sester působilo v okresní nemocnici v Počátkách. V táborské okresní nemocnici je uveden kolektiv 18 řeholních sester a ve strakonické okresní nemocnici 15 sester. Nejdéle působily sestry boromejky v okresní nemocnici v Českých Budějovicích, kde byly dle katalogu již od roku $1850 .^{3}$

Pro srovnání pražský arcidiecézní katalog k roku 1948 uvádí, že na území arcidiecéze působilo celkem 417 sester boromejek, a to na třinácti místech. ${ }^{4}$

\footnotetext{
2 Jako základní literaturu uvádějící do tématu zmiňme monografii Ludvík JIRÁSKO, Církevní ráády a kongregace v zemích Českých, Praha: Fénix, 1991. Specifickou slovenskou problematiku vztahu komunistické státní moci k ženským řádům a řeholím přibližuje kupř́kladu zasvěcená monografie Jan Milan DUBOVSKÝ, Akcia rebolníčky, Martin: Lúč, 2001. K problematice sester boromejek uved'me monografii týkající se „hlavní hrdinky“ z řad kongregace v období komunistické totality: Marie HOLKOVÁ, Matka Vojtěcha - Vyprávění o velké služebnici Boží, Brno: Cesta, 1992. K související problematice jihočeského regionu upozorňuji na monografii Zdeněk DEML, Pod dobledem církevních tajemnikui, Brno: CDK, 2008. Tato monografie je de facto upravená verze disertační práce tohoto autora, která byla obhájena na TF JU v Českých Budějovicích v roce 2008 a zaobírá se zejména problematikou omezování liturgického života církve v jihočeském regionu na vybraných př́kladech. Také nesmí být opomenuta studie, ve které autor poukazuje na zákeřné metody používané komunistickou státní mocí při přesvědčování řeholnic, aby opustily řeholi a odešly do civilního života. Srov. Martin WEIS, Přesvědčovací akce „svlékni hábit“ ve světle archivních materiálů, Studia theologica 3/2009, s. 63-76.

3 Catalogus saecularis et regularis cleri dioeceseos Bohemo-Budvicensis pro Anno Domini 1948 (dále CCB 1948)

s. $182-186$.

4 Srov. Catalogus cleri archidioeceseos Pragensis Anno Domini 1948, s. 290-292.
} 
Po únorových událostech roku 1948, již v prosinci téhož roku, došlo k zestátnění nemocnic, což ale na jihočeský region, co se týče vztahu k duchovní péči o nemocné, nemělo žádný dopad. Kupř́íkladu v Praze však byla sestrám boromejkám zestátněna nemocnice pod Petřínem, ze které se stala pobočka Státní fakultní nemocnice v Praze. Boromejky sice zatím stále působily na svých místech v nemocnici, ale již v srpnu 1952 byly z nemocnice vyhnány a většina sester byla převezena do textilních továren.

Když se v únoru 1948 moci ve státě chopila Komunistická strana Československa, nastalo postupné omezování církevního života ve státě. To se odrazilo i v možnostech pastorace nemocných duchovními. Nejdřive došlo z př́kazu orgánů komunistické moci k odstranění křrižů $\mathrm{z}$ veřejných prostor nemocnic. To se samozřejmě neobešlo bez protestů ze stran věřícího personálu nemocnic i věřících pacientů. Situaci nakonec řešil sám ministr zdravotnictví Josef Plojhar. Protože chtěl při vyjednávání mezi státem a katolickou církví ukázat, jaký má politický vliv, nařídil do nemocnic vrátit kř́že a nechal je umístit i tam, kde dříve nebyly - v soukromých pracovnách primářů a vedoucích oddělení. To dosvědčuje kupř́kladu diskusní př́íspěvek krajského tajemníka KSČ, ve kterém doslova uvádí následující: „Plojhar zasahuje do otázek, které nejsou v jeho pravomoci, např́íklad do nemocnic, kde chtěli naši soudruzi sundat kř́že. Ministr Plojhar to zrušil a chce dát kř́iže i tam, kde nikdy dříve nebyly. Např́klad do soukromých ordinací primářu. Ministr chce biskupu Hlouchovi ukázat svoji sílu a bude to stát 10000 Kč..." $\mathrm{Na}$ druhou stranu nutno v rámci objektivity přiznat, že co se týče vysluhování svátostí, duchovních rozhovorů s nemocnými a podobně, duchovenstvo nebylo $\mathrm{v}$ této záležitosti omezováno. Až v roce 1952 dochází $\mathrm{k}$ omezování udělování některých svátostí $\mathrm{v}$ nemocnicích, a to pravidelného vysluhování mše svaté pro veřejnost či udělování křtu. Tuto skutečnost nám kupř́kladu dokazuje prudký zlom v počtu pokřtěných, uvedený ve farní matrice římskokatolické farnosti Tábor, kde počet křtů klesl v jednom roce z 988 na 303, nebot byly na návrh zdravotního referenta ze zdravotních důvodů zakázány. ${ }^{6}$

Státní úřad pro věci církevní v Praze přišel v roce 1955 s jednotným plánem pro celé Čechy, že náboženské úkony mají být trpěny na pokojích pacientů pouze v př́padě tzv. posledního pomazánís tím, že duchovní mají při této př́ležitosti přísně zakázáno provádět mezi pacienty tzv. agitaci. Křty měly být $z$ nemocnic - porodnic - odstraněny. Existovala samozřejmě výjimka, kterou mohl schválit př́slušný církevní tajemník a která se týkala př́padu tzv. "mimořádného politického zájmu“"?

Ovšem, jak mnozí představitelé komunistického režimu v nemocnicích či místní státní správě nelibě nesli, bylo mnoho řeholnic, které pacienty do svých kaplí zvaly, a bylo též i mnoho duchovních, kteř́ sice měli státní souhlas pouze pro duchovní službu u kolektivu řeholnic, ale přesto skrytě provozovali mezi nemocnými duchovenskou péči označovanou za nepřátelskou agitaci. Problematiku nemocničních kaplí a vysluhování svátostí ke spokojenosti představitelů režimu proto „vyřešilo“ až definitivní odstranění řeholnic

5 Srov. SOA Třeboň, Fond Jihočeský krajský výbor Komunistické strany Československa (dále Jč KV KSČ), fascikl č. 25, signatura I/141, plénum Jč KV KSČ 1949, strojopisný záznam referátu s. Holuba.

6 Srov. Ř́mskokatolická farnost Tábor, kniha pokřtěných. Zápisy k roku 1952 a 1953. Jak uvádí ve své monografii Zdeněk Deml, celá situace ohledně zákazu křtů v táborské nemocniční kapli byla iniciována stížností českobudějovického církevního tajemníka, který ve svém dopise Státnímu úřadu pro věci církevní v Praze navrhuje, aby nemocniční kaple sloužily pouze „k soukromým potřebám řebolnic - ošetrovatelek“. Srov. Zdeněk DEML, Pod dobledem církevních tajemníkư, s. 178.

7 Tamtéž s. 146-147. 
z nemocnic a zrušení nemocničních kaplí, které byly proměněny v lůžkové pokoje, kulturní místnosti s televizí či dokonce sklady civilní obrany. Vnemocnicích zůstalo již jen sporadické vysluhování svátosti smíření a svátosti nemocných a záleželo mnohdy na velké odvaze a důvtipu duchovního či prŕbuzných nemocného, aby tato forma pastorace nemocných byla vykonávána.

\section{Situace řeholnic v jižních Čechách po roce 1950}

Komunistická státní moc v Československu usilovala od roku 1950 o zlikvidování či alespoň radikální omezení i existence ženských řeholí a řádů, což mělo samozřejmě negativní dopad i na pastoraci nemocných $\mathrm{v}$ nemocnicích, kde řeholní sestry působily. Je jisté, že mnohé řeholnice těžce nesly zvyšující se tlak státní moci, a tak se dochovalo krásné svědectví, které líčí, jak českobudějovický biskup Josef Hlouch ještě v březnu 1950 unikl z internace ve své rezidenci, aby v nastávajících okamžicích zkoušky posílil řeholní sestry duchovním slovem a požehnáním. Bezpečnostní referent př́slušného ONV si ve svém přípise stěžuje, že to bylo dokonce za pomoci personálu nemocnice a mlčenlivého souhlasu místní organizace KSČ: „Dne 25. 3. 1950 o 18. hod. dozvěděl jsem se, že následující den, tj. 26. 3.1950 má navštíviti Strakonice biskup Hlouch. Dal jsem proto orgánům NB př́kaz, aby celou záležitost sledovaly. Z hlášení ještě podotýkám, že správa zdejší státní oblastní nemocnice návštěvu českobudějovického biskupa zdejšímu ONV nehlásila, ač o ní byla informována a vrchní správce této nemocnice s. Josef Kahuda dal pro dopravu biskupa Hloucha z Českých Budějovic do Strakonic a zpět vlastní auto osobní k disposici. Ani ZO KSČ v uvedené nemocnici, ač o návštěvě měla vědomost, tuto okolnost nesdělila odpovědným orgánům strany..." 8

O několik dní později přichází uměle vykonstruovaný proces s představiteli řádů, který proběhl ve dnech 31 . března -5 . dubna 1950 . Poté byly v noční policejní razii zabrány mužské řeholní kláštery dne 13. dubna 1950 a řeholníci odvezeni do tzv. soustřed'ovacích či internačních klášterů. Poté následovalo administrativní omezování činnosti řeholnic a jejich přemístění do tzv. „centralizačních“ klášterů. Akce na likvidaci ženských řeholních společenství neprobíhala, na rozdíl od likvidace mužských řádů, pouze $\mathrm{v}$ jediný den, ale byla rozložena přibližně od srpna do ř́ina roku 1950. Celkem bylo likvidováno asi sedm set ženských klášterů a internováno v celém Československu více než 10000 řeholnic. ${ }^{9} \mathrm{Jak}$ jsme již uvedli v jiné své stati, pobyt řeholních sester v centralizačních klášterech byl značně tvrdý. ${ }^{10}$ Každý centralizační klášter měl svého vedoucího, respektive vedoucí, bez je(jí)hož svolení nikdo nesměl řeholnice navštívit. Kdo chtěl požádat o návštěvu některé řeholnice, musel vyplnit velice důkladný formuláŕ, ve kterém nechyběly jak osobní údaje žadatele a navštívené řeholnice, tak také patř̌ičné „odůvodnění“ pro návštěvníky centralizačního kláštera, proč se tak činí. Přestože formulář obsahoval ujištění, že se tím nikterak nezamezuje právo navštívit řeholní setry, záleželo jen na libovůli státního správce kláštera, zda návštěvu dovolí, či pod záminkou politických nebo zdravotních důvodů odmítne. ${ }^{11}$

8 SOA Třeboň, fond Jč KNV České Budějovice, karton č. 146, signatura 370, hlášení ONV Strakonice krajskému církevnímu tajemníkovi ze dne 27. 3. 1950, rukopis, originál, signovaný.

9 Srov. Václav VAŠKO, Neumlčená, s. 191.

10 Srov. Martin WEIS, Přesvědčovací akce, s. 67.

11 Srov. originál přihlašovacího lístku in SOkA Jindřichův Hradec, fond ONV Dačice, karton č. 679, složka kláštery. 
Nejdříve byly donuceny opustit své působiště řeholnice na „exponovaných“ místech, tedy ve školství a význačných nemocnicích, kde by mohly „nepatřičně“ ideologicky působit na široké masy pracujícího lidu. Byly soustředěny do centralizačních klášterů nebo přeloženy do ústavů sociální péče, kde přicházely do styku vesměs jen s lidmi přestárlými či duševně chorými. Tam, kde řeholnice nemohly být $\mathrm{z}$ důvodu nutné péče o pacienty odsunuty ihned, mohly na nějaký čas nadále působit. Byly ale podrobovány př́ísným ideologickým prověrkám a hrubému zasahování i do vnitřní samosprávy řeholní komunity. ${ }^{12}$

Př́pis krajského církevního tajemníka v Českých Budějovicích přibližuje, že ne všude okresní církevní tajemníci věnovali řeholním sestrám odpovídající pozornost a ještě v roce 1952 se v této práci vyskytovaly „závažné nedostatky“, zejména co se týče řeholních sester působících v okresních nemocnicích. ${ }^{13}$

Tyto „nedostatky“ v práci okresních církevních tajemníků přetrvávaly i do dalších let, a tak můžeme ještě v roce 1955 nalézt velice tvrdé hodnocení kolektivů řeholních sester: „Řeholnice v kraji českobudějovickém, zejména pak ty, které působí v nemocnicích, nemají $\mathrm{k}$ našemu zřízení kladný poměr a snadno se nechají využít pro politické zájmy reakce. To se v kraji projevilo zejména při volbách, $k d y 41 \%$ řeholnic se přes všechno úsilí odmítlo zúčastnit voleb. Nejreakčnějším kolektivem jsou řeholnice v Českých Budějovicích, které na př́klad ve volbách do Národního shromáždění dávaly do uren většinou klosetový papír. $S$ tímto kolektivem řeholnic se často scházejí i reakční kněží, působící v Českých Budějovicích. " ${ }^{14}$

Tato skutečnost byla zřejmě i příčinou toho, že v roce 1956 byly sestry boromejky, působící v pěti okresních nemocnicích, odsunuty mimo území českobudějovické diecéze. Dochoval se velice dojemný dokument, který líćí reakci diecézního biskupa Josefa Hloucha na tento odsun řeholních sester $\mathrm{z}$ českobudějovické diecéze. Velice pozoruhodná na tomto dokumentu je skutečnost, že vznikl již v době př́sné internace diecézního biskupa mimo území českobudějovické diecéze. Dopis se z internace dostal k řeholním sestrám nejspíše „pronesením“ od některé z povolených návštěv biskupa. Dopis je vlastnoručně biskupem signován, napsán na běžném listu papíru o formátu A4. Papír nemá žádnou hlavičku ani znak biskupa. Též bohužel nenese ani datum napsání, a proto můžeme jen dle jeho obsahu usuzovat, že byl napsán před svátkem navštívení Panny Marie v roce 1956, tedy před 2. červencem $1956 .{ }^{15}$ I ve velmi ztížených podmínkách nalezl biskup Hlouch slova díků a povzbuzení pro řeholnice, které vynuceně opouštěly místa svého působiště. $V$ celém textu tohoto dopisu se zrcadlí biskupovo milující srdce a jeho hluboká eucharistická spiritualita, když jeden z nejbolestnějších důsledků odchodu řeholních sester z nemocnic vidí v tom, že

12 Srov. Martin WEIS, Přesvědčovací akce, s. 68.

13 Srov. SOkA Písek, fond ONV Milevsko, karton č. 125, signatura 291.5, strojopis, originál, signovaný ze dne 17.11. 1952.

14 Církevní tajemník mínil oněmi „reakčními kněžími“ českobudějovické duchovní, kteří pravidelně po duchovní stránce pečovali o nemocné vysluhováním svátostí či duchovním rozhovorem. Nejčastěji je v dokumentech uváděno jméno kaplana P. Škopka. SOA Třeboň, fond KNV České Budějovice, karton č. 691, složka círk./ 3 - Schůze byra KV KSČ v Č. Budějovicích dne 31. 3. 1955. Zpráva o církevně politickém vývoji v kraji Č. Budějovice (podává s. Krejčí) - rukopis, originál.

15 Biskup Josef Hlouch prošel několika fázemi internace a omezení osobní svobody. Prvé omezení přišlo již 17. června 1949 dosazením tzv. vládního zmocněnce do biskupského úřadu a násilným zabráním za policejní asistence prostor kurie. Další fáze přišla v únoru 1950, když byla biskupu Hlouchovi dána tzv. „osobní ochrana“, tj. na všech cestách jej doprovázel příslušník StB, který hlídal i budovu biskupství a kontroloval všechny příchozí. Od června 1950 následovala př́ísná izolace biskupa v budově rezidence, během níž měl k biskupovi př́stup jen státem dosazený generální vikář Buchta, vládní zmocněnec a dvě řeholní sestry. Roku 1952 byl biskup Hlouch odstraněn z diecéze a na jeho místo byl fiktivní volbou dosazen dosavadní generální vikář Josef Buchta. Internaci biskup opustil až v době politických změn v našem státě roku 1968. Srov. Martin WEIS, Přesvědčovací akce, s. 69. 
bude eucharistie odnesena $z$ nemocničních kaplí, a nemocní tak ztratí nadpřirozený zdroj útěchy. Na druhý - mariánský - rozměr spirituality biskupa Josefa Hloucha ukazují jeho slova požehnání: „Provázejž Vás Pán Bůh, budiž s Vámi Panna Maria Matka Neposkvrněná, která se Vás jistě zvláště ujímá, jak to Bůh naznačuje, když odcházíte na svátek jejího Navštívení. Kéž tento den zanotí Vaše duše pokorné Magnificat, které z těch srdcí nic nevyrve a neutlumí a které přehluší všechen řev bezbožeckého světa a křik všech protivenství." $V$ dopise se ale nalézají i slova naděje, že když Bůh dopustí, aby se nějaké požehnané dílo bořilo, že tak činívá proto, že bude stavět. Biskup končí slova povzbuzení zvoláním adresovaným do budoucna: „A Pán Bůh stavět bude!“16

Tento dopis ale také dokumentuje roli řeholních sester, kterou měly ve vztahu k nemocným v oblasti duchovní péče:

„Jako řehole byly jste $\mathrm{v}$ našich městech a krajích ohniskem př́kladného života a nadměrných zásluh. Váš biskup a Vaši kněží na vás spoléhali, k Vám se utíkali, o Vaše modlitby prosili, když šlo o velké starosti v království Božím, když často podléhali v moři soužení a útrap, když klesali pod tíží křížủ. Sám Otec náš ví, jakými pevnostmi království Božího byly ty vaše doby, ty nemocniční kaple, ano i ty koutečky Vašich nočních služeb, kde jste bdívaly $s$ růžencem a nábožnou knihou na modlitbách čekajíce, až některý nemocný zavolá, odkud jste s tichým krokem spěchávaly poohlédnout se, zdali některý nemocný pomoci nepotřebuje. Poněvadž není možno vystihnout dobroty Boží, je těžko vystihnout všechno požehnání, všechno světlo, sílu i všechny vnější milosti, kterých se našim krajům dostalo skrze Vás (...). ${ }^{\text {"17 }}$

\section{Slovenské řeholnice v Čechách}

V souvislosti se situací řeholních sester v Čechách je nutno zmínit také situaci slovenských řeholních sester, které byly ve velké většině odsunuty do Čech. Stejně jako na území Čech došlo i na Slovensku k ráznému zásahu do života ženských řeholí a více než 2000 řeholnic bylo z míst svých působišś odvezeno do tzv. centralizačních klášterů. Jelikož se Slovenskému úřadu pro věci církevní $\mathrm{v}$ Bratislavě zdálo, že i přes tento zásah se nepodařilo řeholní život slovenských řeholnic paralyzovat, dohodl se se Státním úřadem pro věci církevní v Praze na přesunu slovenských řeholnic do Čech s tím, že měly být zaměstnány výhradně manuální prací v textilních továrnách ve vylidněném severočeském pohraničí. Tento přesun slovenských řeholnic proběhl ve třech etapách, a to 12.10.1951, kdy bylo odsunuto 330 řeholnic, 20.10.1951, kdy bylo odsunuto 460 řeholnic, a 21.11. 1951, kdy bylo odsunuto 79 řeholnic. Jak se postupně i na Slovensku dařilo nahrazovat kolektivy řeholních sester v nemocnicích laickými sestrami, byly i tyto řeholní sestry přesouvány do Čech. Statistiky uvádí, že v dalších letech až do roku 1961 bylo takto ze Slovenska odsunuto do Čech dalších 230 řeholních sester. Tyto sestry, jak bylo naplánováno, pracovaly v továrnách a ani $\mathrm{v}$ době tzv. zákonné dovolené na zotavenou nesměly navštívit svůj domov - Slovensko. Až v 60. letech 20. století dostaly možnost opustit továrny a pracovat na území Čech v sociálních

16 Originál dokumentu v majetku rodiny biskupa Hloucha.

17 Tamtéž. 
službách, a to zejména $v$ domovech důchodců či v ústavech pro duševně choré, a tak přinášet světlo křestanského milosrdenství nemocným a seniorům. ${ }^{18}$

\title{
Závěrem
}

Po radikálním snížení počtu řeholních komunit na území diecéze v roce 1956 působily řeholní sestry již jen na několika málo místech v diecézi. Ani období politického uvolnění $\mathrm{v}$ roce $1968 \mathrm{v}$ tomto nepřineslo nějakou výraznou změnu. Bylo př́liš krátké na to, aby mohl být plně obnoven život řeholních komunit, a v nastalém období tzv. normalizace opět došlo k utužení státního dozoru nad církvemi včetně působení řeholních komunit. Pastorační péče o nemocné tak zůstala omezena pouze na duchovní, kteří měli tzv. státní souhlas k výkonu duchovenské služby a kteři tak mohli činit, pokud tomu ovšem nebránil chod nemocnice či zákaz ošetřujícího lékaře.

\section{Odstranění řeholních sester z jihočeských nemocnic komunistickým režimem a jeho dopad na pastoraci nemocných}

\begin{abstract}
Abstrakt
Po únoru 1948 nastalo postupné omezování církevního života ve státě. Komunistická moc v Československu usilovala mimo jiné i o radikální omezení působení ženských řeholí a řádů, a to na exponovaných místech, jako bylo školství a veřejná zdravotní péče. Nejdřive byly v noční policejní razii dne 13. dubna 1950 zabrány mužské řeholní kláštery a řeholníci odvezeni do tzv. soustřed'ovacích či internačních klášterů. Poté následovalo administrativní omezování činnosti řeholnic a jejich přemístění do tzv.,,centralizačních“ klášterů. Tato opatření měla velmi negativní dopad na duchovní péči o pacienty městských a okresních nemocnic v jihočeském regionu, jak na základě archivních materiálů dokumentuje tato studie.
\end{abstract}

Klíčová slova: církevní dějiny, pastorace nemocných, řeholnice, komunistický režim, perzekuce řeholnic

\section{Removal of Nuns from South Bohemian Hospitals by the Communist Regime and Its Impact on Pastoral Care of Patients}

\begin{abstract}
After February 1948 gradual circumscription of ecclesial life in the state began to take place. The communist authorities in Czechoslovakia sought, inter alia, to radically reduce the activities of female religious orders mainly in exposed areas such as education and public health care. First, on 13 April 1950, during a night raid, the police seized monasteries and the monks were taken to so-called "concentration" or internment monasteries. Then administrative restrictions on the activity of nuns and their transfer to so-called "centralization" cloisters followed. Those
\end{abstract}


measures had a very negative impact on spiritual care of patients in town and district hospitals in the South Bohemian region, as documented by this study based on archive materials.

Keywords: church history, pastoral care of patients, nuns, communist regime, persecution of nuns

\section{Kontakt na autora}

Prof. ThLic. PaedDr. Martin Weis, Th.D.

Jihočeská univerzita v Českých Budějovicích

Teologická fakulta, Katedra teologických věd Kněžská 8, 37001 České Budějovice

weis@tf.jcu.cz 